\title{
Orthognathic Surgery Associated with Condylectomy for Treatment of Mandibular Osteochondroma: Case Report
}

\author{
Cirugía Ortognática Asociada con Condilectomía para el \\ Tratamiento del Osteocondroma Mandibular: Informe de un Caso
}

lago Demétrio da Silva; Andressa Bolognesi Bachesk; Guilherme Paladini Feltrin; Willian Pecin Jacomacci \& Ângelo José Pavan

DA SILVA, I. D.; BACHESK, A. B.; FELTRIN, G. P.; JACOMACCI, W. P. \& PAVAN, Â. J. Orthognathic surgery associated with condylectomy for treatment of mandibular osteochondroma: case report. Int. J. Odontostomat., 15(3):748-755, 2021.

\begin{abstract}
Osteochondroma is a common benign bone tumor and although its involvement in facial bones is rare $(0.6 \%)$, it shows a strong predilection for developing in the mandibular condyle, causing occlusal changes and facial asymmetry. The aim of this study was to report a clinical case and the treatment of a 43-year-old male patient, who was diagnosed with condylar osteochondroma. Clinically, the patient presented an increase in volume in the right condylar region, deviation of the mandible to the left side and malocclusion. His main complaint was his facial asymmetry. Imaging exams showed changes in the size and morphology of the right condyle, and signs of hyper-capture on scintigraphy. The hypothesis of condylar hyperplasia and osteochondroma was raised. A virtual planning and execution of an orthognathic surgery of the jaws was performed to correct the occlusion and facial asymmetry, besides a low condylectomy to remove the lesion. Procedures such as high, low, proportional condylectomy, orthognathic surgery and TMJ reconstructive surgery are alternatives for the treatment of these pathologies. In our case, the orthognathic surgery combined with a condylectomy proved to be promising, to correct the occlusion and the facial asymmetry of the patient.
\end{abstract}

KEY WORDS: condylectomy, facial asymmetry, orthognathic surgery, osteochondroma.

\section{INTRODUCTION}

Osteochondroma is described as the most common benign bone tumor in mandibular condyles, representing 35 to $50 \%$ of all benign tumors and $8 \%$ to $15 \%$ of primary bone tumors (Karras et al., 1996). It is defined as an exophytic lesion covered by a cartilaginous capsule, with excessive growth on the bone surface that formed from endochondral ossification. Its occurrence is more frequently reported in the fourth decade of life, with a predilection for women (Forssell et al., 1985; Goyal \& Sidhu, 1992; Roychoudhury et al., 2011).

When the lesion affects a mandibular condyle, clinical presentations may include malocclusion with unilateral posterior open bite on the affected side, displacement of dental midline and chin to the contra lateral side, transverse cant of the occlusal plane, progressive facial asymmetry secondary to vertical stretching of the face on the affected side and temporomandibular joint (TMJ) dysfunction (Kaneda et al., 1982; Wolford et al., 2014b; Mehra et al., 2016). Radiographically, it presents as a unilateral lesion, which promotes deformation and increased of mandibular condyle size, commonly associated with dentofacial deformity (Mehra et al.).

Various treatment alternatives for condylar osteochondroma and secondary dental and facial deformities are described in literature as surgical excision of the lesion by high or low condylectomy, condyle reconstruction, and may be associated with orthognathic surgery and orthodontic treatment. Low condylectomy in association with orthognathic surgery has been described as the more effective treatment 
because it corrects the facial asymmetry and enucleate the lesion in one surgical time, avoiding the occurrence of possible residual asymmetries and malocclusion while performing only a low condylectomy (Kaneda et al.; Wolford et al., 2014b; Li et al., 2014). The aim of this paper is to report a clinical case of a 43-year-old male patient, diagnosed with facial asymmetry, pattern III and osteochondroma, affecting the right mandibular condyle, which was submitted to a low condylectomy, orthognathic surgery, and orthodontic treatment, obtaining success in all the treatment.

\section{CASE REPORT}

A 43-year-old male patient during an initial consultation reported a complaint that 3 years ago his
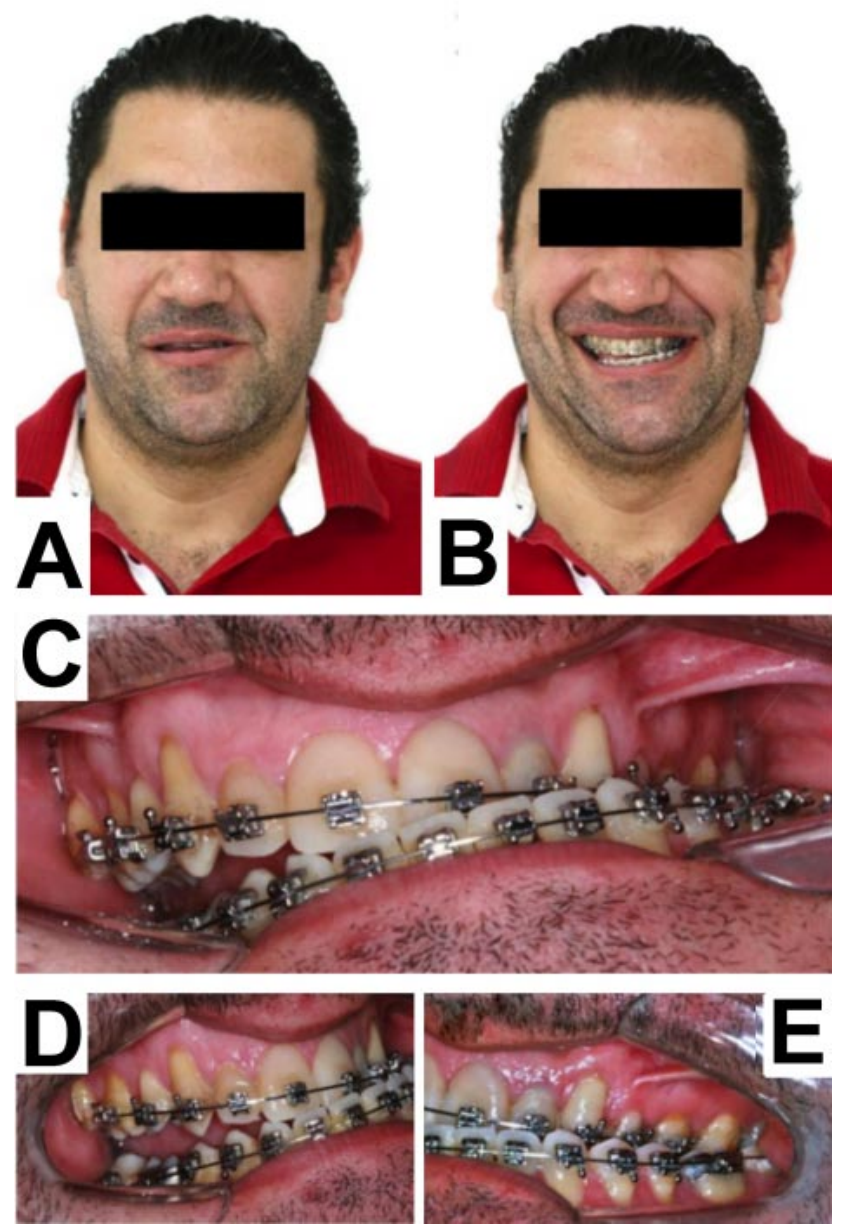

Fig. 1 Initial photographs. (A) Front view with patient in rest position. (B) Front view with patient smiling showing facial asymmetry with severe mandibular laterognathism to the left side. (C) Malocclusion. (D) Posterior open bite. (E) Posterior cross bite. face and occlusion started to develop asymmetry, which prompted him seek orthodontic treatment, but this treatment did not meet his expectations. The orthodontist therefore, referred the patient to specialized assistance in Oral and Maxillofacial Surgery. On physical examination an increase in volume was observed in the right condylar region, maxillary retrognathism, severe mandibular laterognathism to the left side, malocclusion with posterior open bite on the right side and posterior cross bite on the left side (Fig. 1). Exams of scintigraphy, cone beam computed tomography, panoramic radiography, teleradiography, magnetic resonance imaging of the right TMJ and preoperative blood tests were requested. Imaging exams showed changes in volume and morphology of the right mandibular condyle (Fig. 2), as well as signs of hyper-uptake in scintigraphy, evidencing metabolic alteration. Blood tests showed values within normal limits. Then, the diagnostic hypotheses of condylar hyperplasia and osteochondroma of the right condyle were raised. From the software Dolphin Imaging \& Management Solutions $®$ $11.93 \mathrm{D}$ version (Dolphin Imaging, Chatsworth, CA, USA) was performed a virtual planning of maxillary and
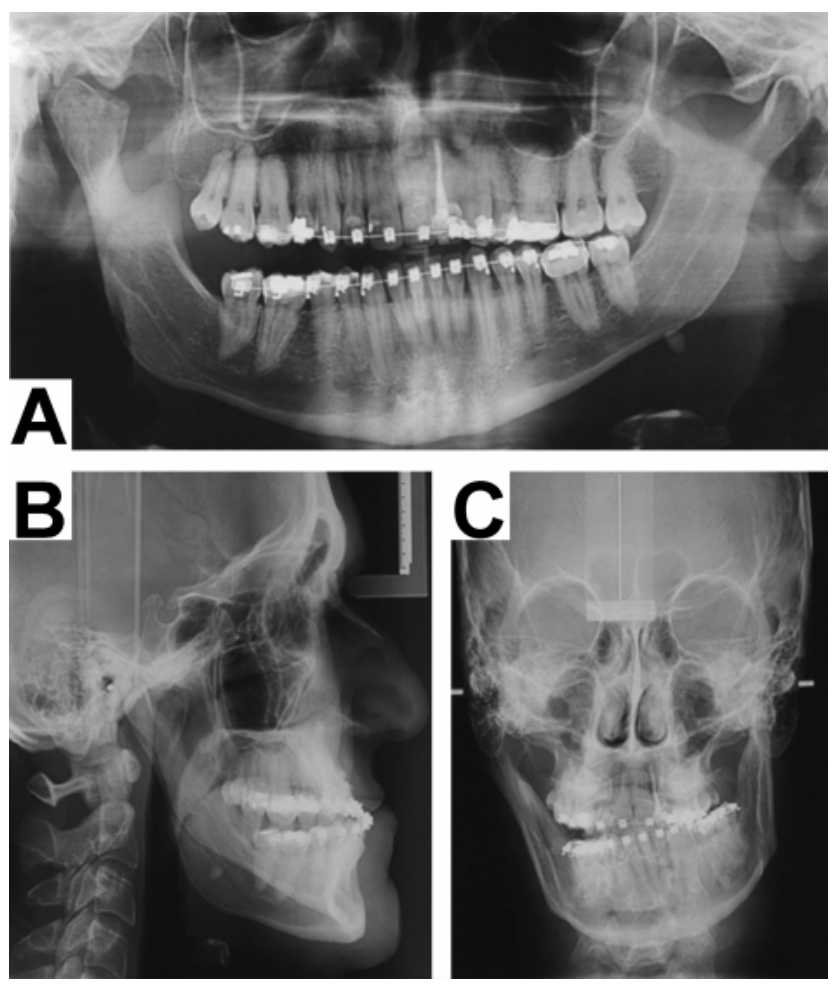

Fig. 2 Initial imaging exams. (A) Panoramic radiography showing the difference in volume and morphology of the right condyle compared to the left condyle. (B) Lateral radiography used for cephalometric tracing and diagnosis of pattern III. (C) Frontal radiography evaluating from the midline the facial asymmetry of the patient. 
mandibular orthognathic surgery associated with low condylectomy of the right condyle (Fig. 3).

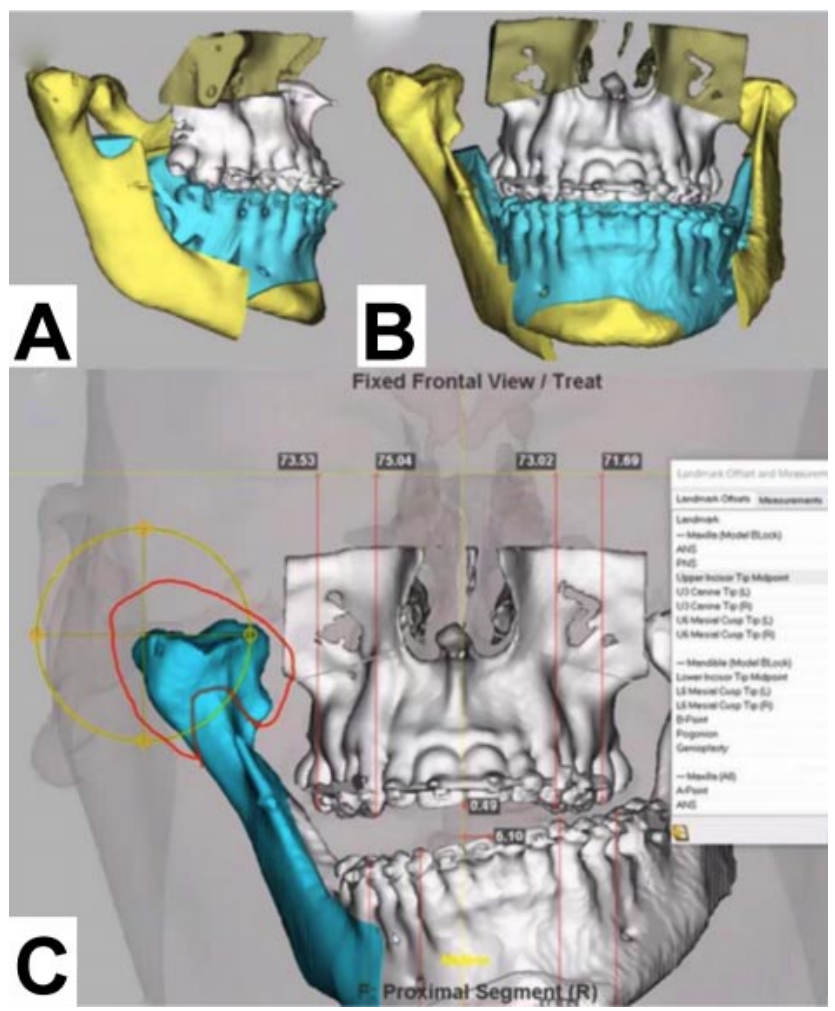

Fig. 3 Virtual planning for maxillary and mandibular orthognathic surgery using Dolphin Imaging \& Management Solutions ${ }^{\circledR} 11.9$ 3D version (Dolphin Imaging, Chatsworth, CA, USA). (A) 3D reconstruction in lateral view. (B) 3D reconstruction in front view. (C) Condylectomy planning of the right condyle.

The surgical procedure was performed under general anesthesia and nasotracheal intubation. Initially, the incision line of the preauricular access was demarcated for access of the right mandibular condyle. Low condylectomy was performed for removal of the tumor mass, which was divided into 6 fragments cut by piezoelectric motor NSK VarioSurg 3. (Fig. 4). The new condylar segment was repositioned in the mandibular fossa to follow up the orthognathic surgery. As planned in the 3D software, the surgery started with the mandible, and vestibular access was performed followed by bilateral sagittal osteotomy of the right and left mandibular ramus. At this stage, the mandibular distal segment was repositioned through the intermediate guide, and the maxillomandibular block was performed (Fig. 5).

With the mandibular condyles properly positioned in the joint pits, the bone segments were fixed with plates and screws of the $2.0 \mathrm{~mm}$ system. The last stage consisted of Le Fort I osteotomy of the maxilla through

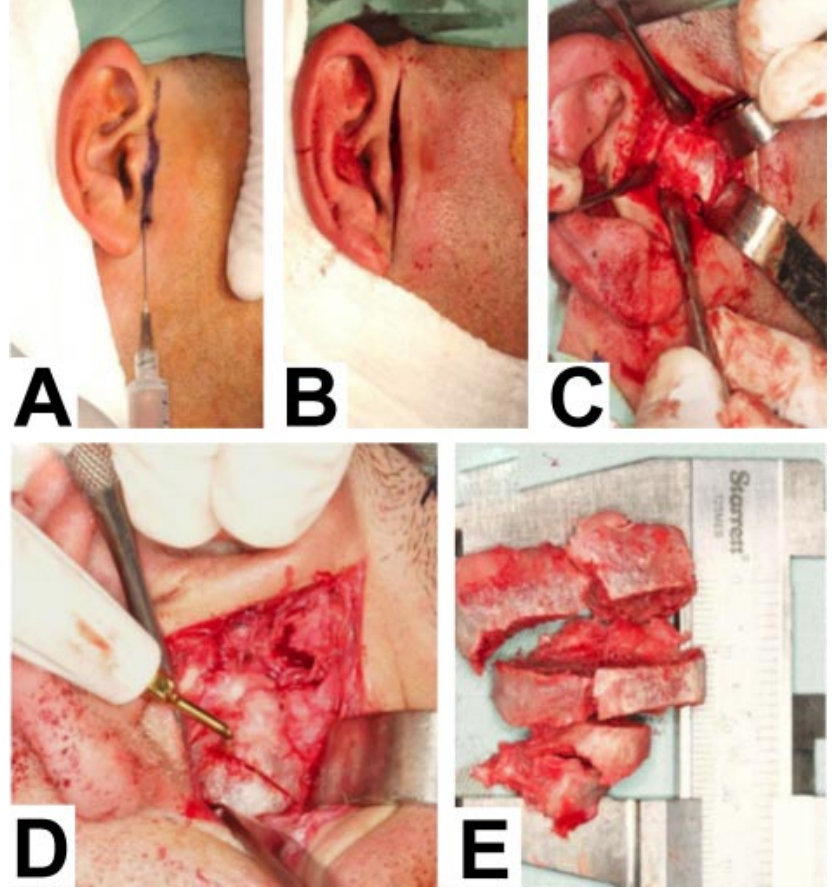

Fig. 4 Surgical procedure being initiated by condylectomy. (A) Demarcation of incision line. (B) Preauricular access. (C) Dissection and access to the right condyle. (D) Condylectomy by piezoelectric motor NSK VarioSurg 3. (E) Fragments removed.

circum-vestibular access, which was repositioned in final occlusion using the final guide and maxillomandibular block, and was followed with fixation with plates and screws of the $2.0 \mathrm{~mm}$ system. The sutures were performed, finishing the procedure without complications (Figs. 6A, B). Functional therapy with elastics was instituted in the immediate postoperative period.

The removed fragments were placed in a formaldehyde container and sent for histopathological analysis, through which the diagnosis of osteochondroma was completed (Fig. 6C). After 14 days postoperatively, stable occlusion was observed and the patient did not show signs of paralysis of any branch of the facial nerve. After 3 months of follow-up, the rubber bands were removed. The patient presented premature contact on the right side and absence of intercuspation on the left side (Fig. 7). At this stage, the patient was referred to the orthodontist to resume orthodontic treatment. After 2 years of follow-up, the patient evolved with correction of facial asymmetry, adaptation of right condyle and preserved oral opening, but continues with orthodontic treatment (Fig. 8). A panoramic radiography in the postoperative periods was requested at 3 months, 6 months, 1 year and 3 

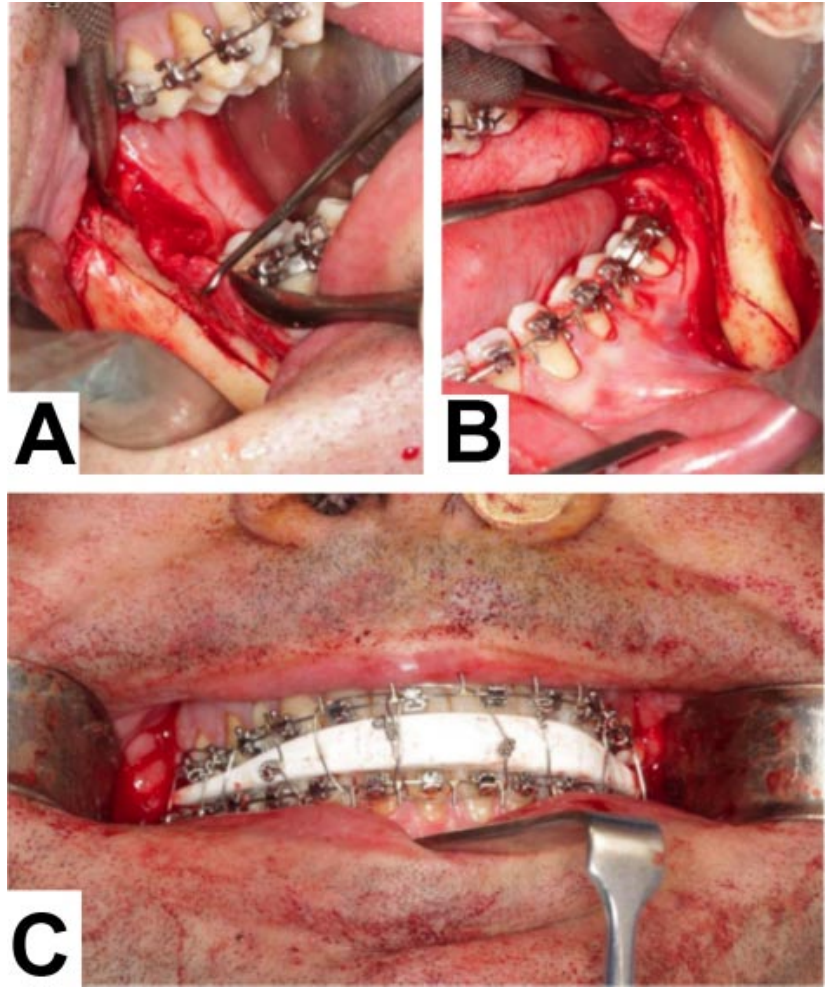

Fig. 5 Execution of orthognathic surgery being initiated by mandible. (A) Bilateral sagittal osteotomy of the right and (B) left mandibular ramus. (C) Repositioning of the distal mandibular segment in the intermediate guide followed by maxillomandibular block.
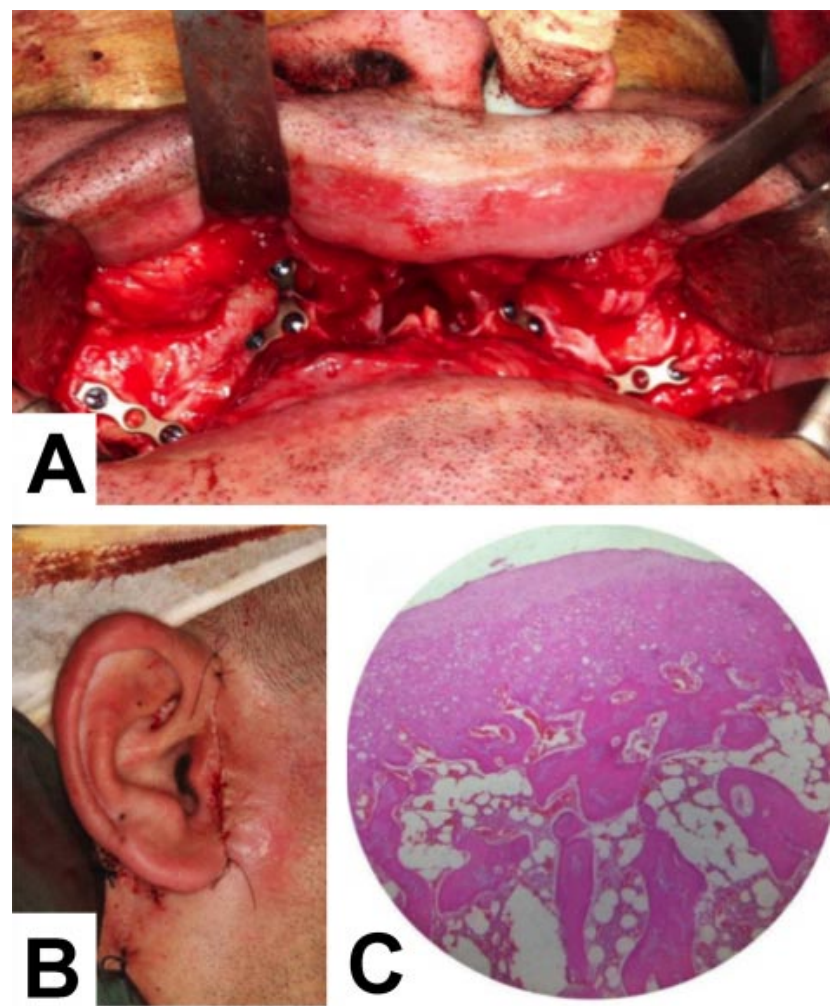
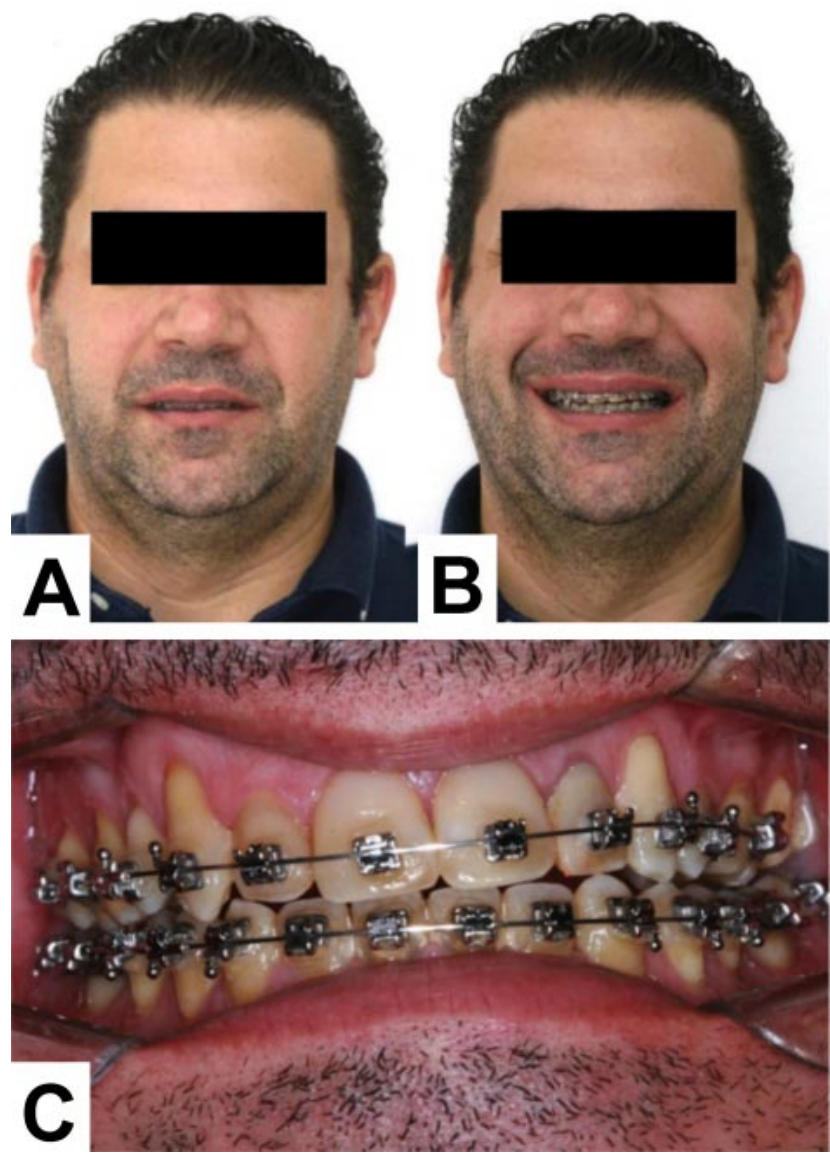

Fig. 7 Three months of follow-up. (A) Front view with patient in rest position. (B) Front view with patient smiling showing an improvementof the facial asymmetry. (C) Occlusion showing premature contact on the right side and absence intercuspation on the left side.

years. No signs of recurrence of the lesion in the right condyle were observed, and the bone segments of the mandible and maxilla showed no alterations in the consolidation and in the position (Fig. 9).

\section{DISCUSSION}

Osteochondroma is a common benign bone tumor, but rarely affects the facial skeleton, with an incidence of only $0.6 \%$ (Morey-Mas et al., 2011). There are reports in the literature of this lesion affecting

Fig. 6 Completion of the surgical procedure. (A) Maxillary replacement and fixation with plates and screws of the $2.0 \mathrm{~mm}$ system. (B) Sutures of preauricular access. (C) Histopathological examination confirming the diagnosis of osteochondroma. 


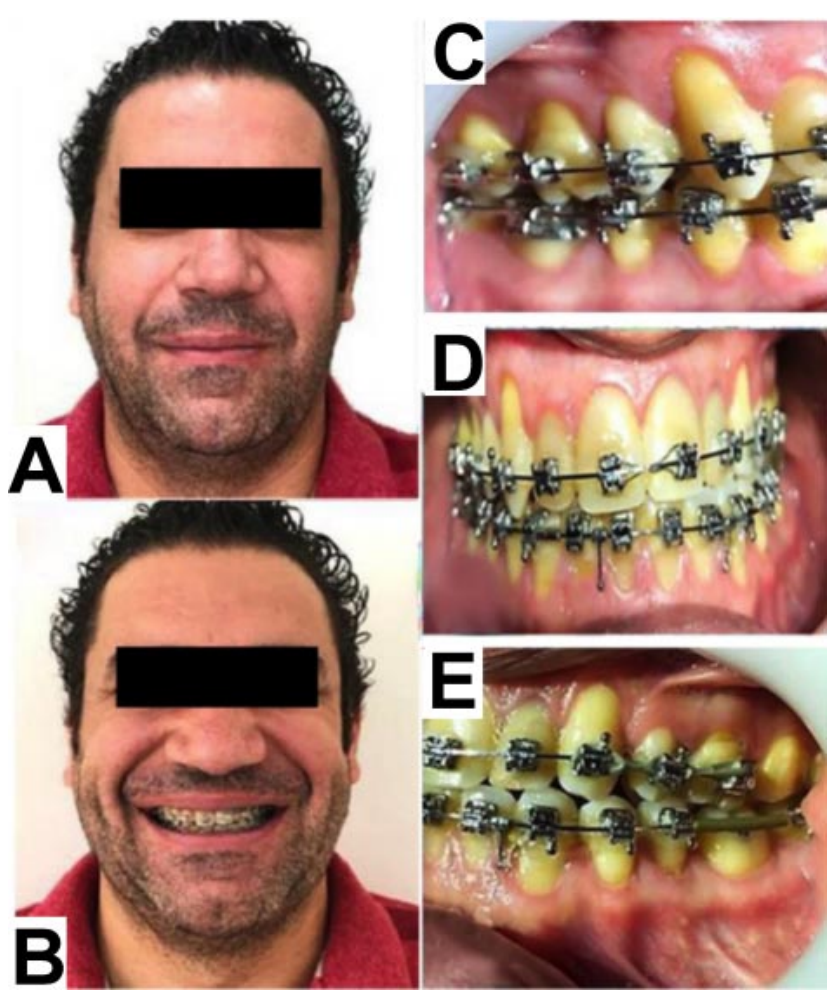

Fig. 8 Two years of follow-up. (A) Front view with patient in rest position. (B) Front view with patient smiling demonstrating the correction of facial asymmetry. (C) Improvement in intercuspation on the right side. (D) Frontal view of the occlusion. (E) Improvement in intercuspation on the left side.
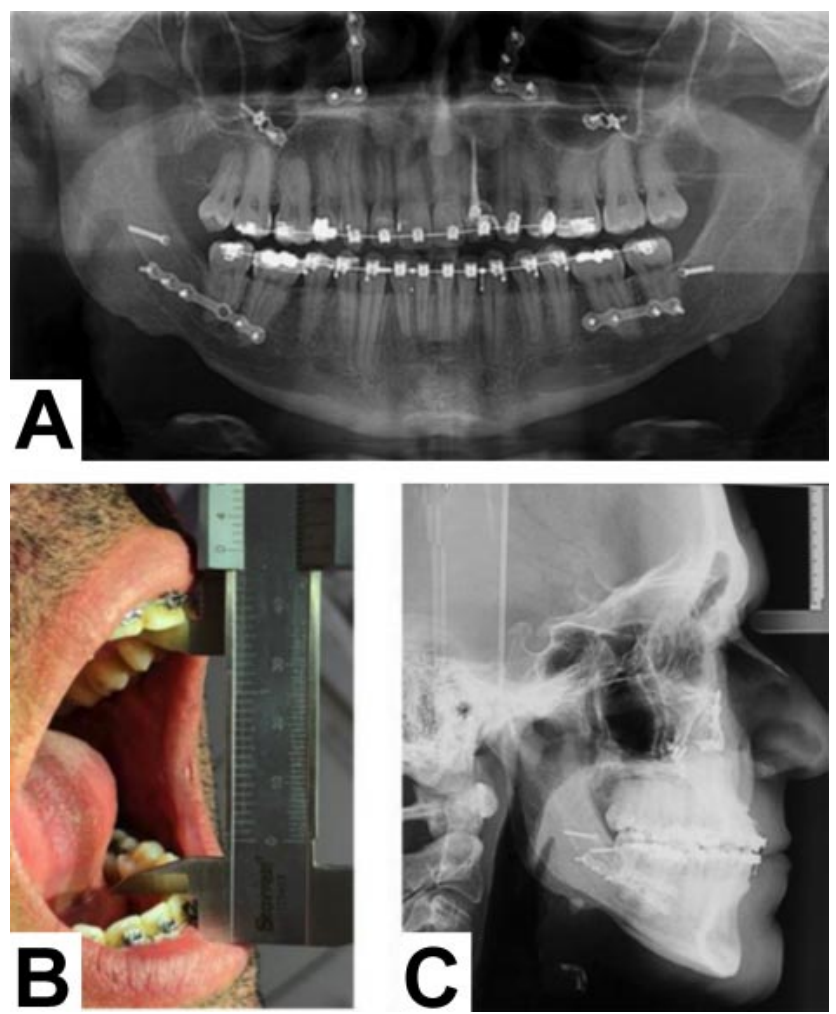

zygomatic arch, cranial base, maxilla, maxillary sinus, nasal septum, coronoid process and mandibular condyle (Brady et al., 1978; Pool et al., 1979; Castillo et al., 1989; Traub etal., 1990; Henry et al., 1992; Kerscher et al., 1993; Vezeau et al., 1995; Barrett et al., 1996; Ord et al., 2010). The etiology remains uncertain, but the theory of existence of aberrant foci of epiphyseal cartilage in the bone cortex is currently the most accepted. It is believed that stress in the regions of tendon insertion, where there are focal accumulations cells with cartilaginous potential, lead to the formation of these tumors. This could explain the fact that in the mandible these lesions often arise in the choroid process, where there is the insertion of the temporal muscle, and in the condylar region in the anteromedial pole, due to the insertion of the lateral pterygoid muscle (Karras et al.; Wolford et al., 2020).

Wolford et al. (2014b) reported that condylar hyperplasia $(\mathrm{CH})$ is a generic term that describes conditions that increase the mandibular condyle, adversely affecting the size and morphology of the mandible, which may involve condyles affected by osteochondroma. Authors also present a simple but comprehensive classification of the various pathological entities of condylar hyperplasia, which are: $\mathrm{CH}$ type 1: the onset occurs during puberty. It is an accelerated and prolonged aberration of the normal condylar growth mechanism, occurring bilaterally $(\mathrm{CH}$ type $1 \mathrm{~A})$ or unilaterally $(\mathrm{CH}$ type $1 \mathrm{~B})$. With growth vector usually in the horizontal direction, is self-limited, with end of growth until 20 years old, generating severe prognathism; $\mathrm{CH}$ type 2: pathological condylar entity, in which osteochondroma is found. It presents unilateral excessive growth of the condyle's head and neck, leading to a vertical mandible elongation, although a horizontal growth vector may occasionally occur. The growth process may continue indefinitely, with progressive worsening of facial asymmetry. In addition, can be subdivided into $\mathrm{CH}$ type 2A: where exist an increase of the head and neck condylar with a vertical growth vector, non-exophytic, and $\mathrm{CH}$ type $2 \mathrm{~B}$ : exophytic; $\mathrm{CH}$ type 3: includes other types of benign tumors that can cause condylar enlargement, such as osteoma, neurofibroma, giant cell tumor, fibrous dysplasia, osteochondroma, chondroblastoma, and

Fig. 9 Final clinical and imaging examination. (A) Panoramic radiography showing the adaptation of the right condyle. (B) Maximum oral opening preserved. (C) Lateral radiography demonstrating the correction of facial pattern III to facial pattern I. 
arteriovenous malformation; and $\mathrm{CH}$ type 4: includes malignant tumors resulting from mandibular condyle that cause condylar enlargement, such as chondrosarcoma, multiple myeloma, osteosarcoma, Ewing's sarcoma, metastatic lesions. In the case reported in this paper, the patient presented vertical stretching of the mandible, and increased volume in the right condyle region; besides presenting occlusal alteration and severe laterognathism; generating facial asymmetry. On histopathological examination of the specimen removed from the patient's condyle, it was possible to complete the diagnosis of osteochondroma, framing the case in type $2 \mathrm{~B}$ of classification of Condylar Hyperplasia.

Treatment modalities vary according to reports in literature, often due to the individuality of each case or even the casuistry of each surgeon. Several surgical methods for the treatment of condylar hyperplasia are reported in studies, such as high, low and proportional condylectomy, besides orthognathic surgery and reconstructive TMJ surgery (Brusati et al., 2010; Villanueva-Alcojol et al., 2011). Mehra et al. mention that the advantage of the technical use of low condylectomy is due to the preservation of the joint, shorter time of operation and recovery, while the disadvantage is that it can't be used when the lesion extends to the neck of the condyle, in this case a total condylectomy is necessary. Fariña et al. (2016) points that proportional condylectomy reduced the need of secondary orthognathic surgery, thus being used as a definitive treatment. Similarly, in the study by Kim et al. (2019) the facial asymmetry of patients was resolved only with the removal of the hyperplastic condyle. Low condylectomy has been more used to treat cases of osteochondroma and active condylar hyperplasia, demonstrating absence of complications, proving that its execution does not restrict the functionality of the joint and allows equalizing the posterior facial heights, between the hyperplastic and healthy sides, besides improving the occlusal alterations (Roychoudhury et al.; Fariña et al., 2015) However, some authors believe that conventional procedures that remove the tumor or restore joint function, neglect the correction of secondary maxillofacial changes resulting from condylar osteochondroma ( $\mathrm{Li}$ et al.). Wolford et al. (2014a) state that when only the affected condyle is treated by low condylectomy, without association with orthognathic surgery, the patient usually evolves with compromised functional and aesthetic results, so that certain residual asymmetries and malocclusion may remain reflecting in the need for posterior orthognathic surgery. Thus, in another study, Wolford et al. (2014a) propose the surgical protocol of treatment for osteochondroma associated with facial asymmetry based on the performance of a low condylectomy in order to remove the hyperplastic mass and reshape the condylar neck to function as a "new" condyle, followed by orthognathic surgery to correct the maxillary and mandibular deformities.

In recent years, with technological development, the use of $3 \mathrm{D}$ surgical simulation has made possible to improve the planning of condylectomy performed simultaneously with orthognathic surgery (Kim et al., 2016; Han et al., 2018) In the case reported, after the treatment of condylar hyperplasia, was visualized in the software that the patient would still evolve with facial asymmetry, so that the planning of orthognathic surgery was carried out in sequence. The advantages of performing the procedures in only one surgical time include: patient submission to only one general anesthesia, simultaneous optimization of occlusion, function and aesthetics, in addition to reducing the treatment time. As disadvantages, the patient may be submitted to a long time under general anesthesia, the operation becomes more stressful and tiring for the surgeon and the execution of TMT surgery combined with orthognathic become difficult, requiring a broad surgeon experience (Mehra et al.; Wolford et al., 2015). For the case reported, due to the severity of asymmetry and malocclusion that the patient developed, the option for the protocol of low condylectomy associated with orthognathic surgery was the most promising option for treatment, since a more conservative option would probably corroborate the authors' statements in the literature of the occurrence of residual asymmetries and malocclusions, and may evolve to another surgical time.

Regarding the remodeling of the new condyle under long-term follow-up, Kim et al. (2016) showed that the remodeling was achieved and the TMJ adapted to the situation without functional problems, the same was observed in our case. There was adaptation of the right condyle and radiographically can be observed a more radiopaque area around the condyle corresponding to the formation of cortical bone.

\section{CONCLUSION}

In view of the forms of treatment for osteochondroma, we applied in our case the approach proposed by Larry M. Wolford due to the dentoskeletal discrepancy that the patient presented. Thus, 
orthognathic surgery combined with condylectomy showed promise in the treatment, since they provided functional and aesthetic improvement, correcting the occlusion and facial asymmetry of the case reported.

DA SILVA, I. D.; BACHESK, A. B.; FELTRIN, G. P.; JACOMACCI, W. P. \& PAVAN, Â. J. Cirugía ortognática asociada con condilectomía para el tratamiento del osteocondroma mandibular: informe de un caso. Int. J. Odontostomat., 15(3):748-755, 2021.

RESUMEN: El osteocondroma es un tumor óseo benigno común y aunque su afectación en los huesos faciales es rara $(0,6 \%)$, muestra una fuerte predilección por desarrollarse en el cóndilo mandibular, causando cambios oclusales y asimetría facial. El objetivo de este trabajo fue informar de un caso clínico y el tratamiento de un paciente de sexo masculino de 43 años, que fue diagnosticado con osteocondroma cóndilar. Clínicamente, el paciente presentaba un aumento en el volumen en la región condilar derecha, desviación de la mandíbula hacia el lado izquierdo y maloclusión. Su principal molestia era su asimetría facial. Los exámenes por imágenes mostraron cambios en el tamaño y la morfología del cóndilo derecho, y signos de hiper-captura en la centellografía. Se planteó la hipótesis de hiperplasia condilar y osteocondroma. Se realizó una planificación virtual y ejecución de una cirugía ortognática de la mandíbula para corregir la oclusión y la asimetría facial, además de una baja condilectomía para extirpar la lesión. Procedimientos como la condilectomía alta, baja y proporcional, la cirugía ortognática y la cirugía reconstructiva de la ATM son alternativas para el tratamiento de estas patologías. En nuestro caso, la combinación de la cirugía ortognática y una condiloectomía resultó ser prometedora, para corregir la oclusión y la asimetría facial del paciente.

PALABRAS CLAVE: condilectomía, asimetría facial, cirugía ortognática, osteocondroma.

\section{REFERENCES}

Barrett, A. W.; Hopper, C. \& Speight, P. M. Oral presentation of secondary chondrosarcoma arising in osteochondroma of the nasal septum. Int. J. Oral Maxillofac. Surg., 25(2):119-21, 1996.

Brady, F. A.; Sapp, J. P. \& Christensen, R. E. Extracondylar osteochondromas of the jaws. Oral Surg. Oral Med. Oral Pathol., 46(5):658-68, 1978

Brusati, R.; Pedrazzoli, M. \& Colletti, G. Functional results after condylectomy in active laterognathia. J. Craniomaxillofac. Surg., 38(3):179-84, 2010.

Castillo, M.; Hudgins, P. A. \& Hoffman Jr., J. C. Lockjaw secondary to skull base osteochondroma: CT findings. J. Comput. Assist. Tomogr., 13(2):338-9, 1989.
Fariña, R.; Olate, S.; Raposo, A.; Araya, I.; Alister, J. P. \& Uribe, F. High condylectomy versus proportional condylectomy: is secondary orthognathic surgery necessary? Int. J. Oral Maxillofac. Surg., 45(1):72-7, 2016.

Fariña, R.; Pintor, F.; Pérez, J.; Pantoja, R. \& Berner, D. Low condylectomy as the sole treatment for active condylar hyperplasia: facial, occlusal and skeletal changes. An observational study. Int. J. Oral Maxillofac. Surg., 44(2):217-25, 2015.

Forssell, H.; Happonen, R. P.; Forssell, K. \& Virolainen, E. Osteochondroma of the mandibular condyle. Report of a case and review of the literature. Br. J. Oral Maxillofac. Surg., 23(3):1839, 1985.

Goyal, M. \& Sidhu, S. S. A massive osteochondroma of the mandibular condyle. Br. J. Oral Maxillofac. Surg., 30(1):66-8, 1992.

Han, B.; Wang, X.; Li, Z.; Yi, B.; Liang, C. \& Wang, X. Hemimandibular hyperplasia correction by simultaneous orthognathic surgery and condylectomy under digital guidance. J. Oral Maxillofac. Surg., 76(7):1563.e1-1563.e18, 2018.

Henry, C. H.; Granite, E. L. \& Rafetto, L. K. Osteochondroma of the mandibular condyle: report of a case and review of the literature. J.Oral Maxillofac. Surg., 50(10):1102-08, 1992.

Kaneda, T.; Torii, S.; Yamashita, T.; Inoue, N. \& Shimizu, K. Giant osteochondroma of the mandibular condyle. J. Oral Maxillofac. Surg., 40(12):818-21, 1982.

Karras, S. C.; Wolford, L. M. \& Cottrell, D. A. Concurrent osteochondroma of the mandibular condyle and ipsilateral cranial base resulting in temperomandibular joint ankylosis: report of a case and review of the literature. J. Oral Maxillofac. Surg., 54(5):640-6, 1996.

Kerscher, A.; Piette, E.; Tideman, H. \& Wu, P. C. Osteochondroma of the coronoid process of the mandible. Report of a case and review of the literature. Oral Surg. Oral Med. Oral Pathol., 75(5):559-64, 1993.

Kim, H. S.; Kim, J. Y.; Huh, J. K. \& Park, K. H. A surgical strategy for severe facial asymmetry due to unilateral condylar overgrowth. Int. J. Oral Maxillofac. Surg., 45(5):593-600, 2016.

Kim, J. Y.; Ha, T. W.; Park, J. H.; Jung, H. D. \& Jung, Y. S. Condylectomy as the treatment for active unilateral condylar hyperplasia of the mandible and severe facial asymmetry: retrospective review over 18 years. Int. J. Oral Maxillofac. Surg., 48(12):1542-51, 2019.

Li, H.; Hu, J.; Luo, E.; Zhu, S. \& Li, J. Treatment of osteochondroma in the mandibular condyle and secondary dentofacial deformities using surgery combined with orthodontics in adults. J. Oral Maxillofac. Surg., 72(11):2295-317, 2014.

Mehra, P.; Arya, V. \& Henry, C. Temporomandibular joint condylar osteochondroma: complete condylectomy and joint replacement versus low condylectomy and joint preservation. J. Oral Maxillofac. Surg., 74(5):911-25, 2016.

Morey-Mas, M. A.; Caubet-Biayna, J. \& Iriarte-Ortabe, J. I. Osteochondroma of the temporomandibular joint treated by means of condylectomy and immediate reconstructionwith a total stock prosthesis. J. Oral Maxillofac. Res., 1(4):e4, 2011.

Ord, R. A.; Warburton, G. \& Caccamese, J. F. Osteochondroma of the condyle: review of 8 cases. Int. J. Oral Maxillofac. Surg., 39(6):523-8, 2010.

Pool, J. W.; Tilson, H. B.; Thornton, W. E. \& Steed, D. L. Osteochondroma of the zygomatic arch: report of case. J. Oral Surg., 37(9):673-5, 1979.

Roychoudhury, A.; Bhatt, K.; Yadav, R.; Bhutia, O. \& Roychoudhury, S. Review of osteochondroma of mandibular condyle and report of a case series. J. Oral Maxillofac. Surg., 69(11):2815-23, 2011.

Traub, D. J.; Marco, W. P.; Eisenberg, E. \& Barrows, G. Osteochondroma of the maxillary sinus: report of a case. J. Oral Maxillofac. Surg., 48(7):752-5, 1990. 
DA SILVA, I. D.; BACHESK, A. B.; FELTRIN, G. P.; JACOMACCI, W. P. \& PAVAN, Â. J. Orthognathic surgery associated with condylectomy for treatment of mandibular osteochondroma: case report. Int. J. Odontostomat., 15(3):748-755, 2021.

Vezeau, P. J.; Fridrich, K. L. \& Vincent, S. D. Osteochondroma of the mandibular condyle: literature review and report of two atypical cases. J. Oral Maxillofac. Surg., 53(8):954-63, 1995.

Villanueva-Alcojol, L.; Monje, F. \& González-García, R. Hyperplasia of the mandibular condyle: clinical, histopathologic, and treatment considerations in a series of 36 patients. J. Oral Maxillofac. Surg., 69(2):447-55, 2011.

Wolford, L. M.; Mehra, P. \& Franco, P. Use of conservative condylectomy for treatment of osteochondroma of the mandibular condyle. J. Oral Maxillofac. Surg., 60(3):262-8, 2002.

Wolford, L. M.; Mercuri, L. G.; Schneiderman, E. D.; Movahed, R. \& Allen, W. Twenty-year follow-up study on a patient-fitted temporomandibular joint prosthesis: the Techmedica/TMJ Concepts device. J. Oral Maxillofac. Surg., 73(5):952-60, 2015.

Wolford, L. M.; Movahed, R. \& Perez, D. E. A classification system for conditions causing condylar hyperplasia. J. Oral Maxillofac. Surg., 72(3):567-95, 2014b.

Wolford, L. M.; Movahed, R.; Dhameja, A. \& Allen, W. R. Low condylectomy and orthognathic surgery to treat mandibular condylar osteochondroma: a retrospective review of 37 cases. J. Oral Maxillofac. Surg., 72(9):1704-28, 2014a.
Corresponding author:

lago Demétrio da Silva

State University of Maringá

Dentistry Department, Maringá

Mandacaru Avenue, 1552

Maringá - PR, 87080-000

Paraná

BRAZIL

E-mail: iagodemetrio95@gmail.com

lago Demétrio da Silva

ORCID: 0000-0002-3591-3278

Andressa Bolognesi Bachesk ORCID: 0000-0002-4123-5186

Guilherme Paladini Feltrin ORCID: 0000-0003-1297-178X

Willian Pecin Jacomacci

ORCID: 0000-0002-2148-4871

Ângelo José Pavan 